\title{
Horizontal Fire Spread in a Contemporary Apartment Based on a Real Fire
}

\author{
Stefanie Schubert-Polzin ${ }^{1}$, Alexander Saupe², Ulrich Krause ${ }^{2}$ \\ ${ }^{1}$ Hochschule Magdeburg-Stendal Department of Water, Environment, Construction and Safety Breitscheidstraße 2, Magdeburg, \\ Germany \\ ${ }^{2}$ Institute of Apparatus and Environmental Engineering, Faculty of Process and Systems Engineering, \\ Otto-von-Guericke-Universität Magdeburg Universitätsplatz 2, Magdeburg, Germany \\ Email: stefanie.schubert-polzin@h2.de
}

How to cite this paper: Schubert-Polzin, S. Saupe, A. and Krause, U. (2019) Horizontal Fire Spread in a Contemporary Apartment Based on a Real Fire. Open Journal of Civil Engineering, 9, 367-385.

https://doi.org/10.4236/ojce.2019.94025

Received: November 5, 2019

Accepted: December 28, 2019

Published: December 31, 2019

Copyright (c) 2019 by author(s) and Scientific Research Publishing Inc. This work is licensed under the Creative Commons Attribution International License (CC BY 4.0).

http://creativecommons.org/licenses/by/4.0/

(c) (i) Open Access

\begin{abstract}
The apartment fire tests comprise a set of two full-scale fire experiments in a dwelling building made from pre-fabricated concrete elements in April 2013. Two apartments were nearly identically furnished and fully instrumented with thermocouples, video cameras and gas extraction probes. The apartments were ignited successively whereupon the fire in the second apartment developed freely to post-flashover conditions and got the main focus in this report. The apartment was completely furnished with contemporary furniture and objects, and had an average fire load density for residential occupancy. A full description of the fire load, ventilation conditions and instrumentation are provided. The focus of this report is primarily to obtain conclusions on the horizontal spread of smoke throughout the apartment during the fire growth period. Velocities of smoke spreading were measured to be in the range below $0.05 \mathrm{~m} / \mathrm{s}$ which means that the smoke migrated over the longest distance throughout the apartment for about 3 to 4 minutes while the flame did not leave the initial fire room. The main aim of the experiments was to collect a comprehensive set of data from a realistic and contemporary fire scenario to validate numerical simulations.
\end{abstract}

\section{Keywords}

Apartment Fire, Horizontal Fire Spread, Smoke Spreading, Full-Scale Fire Test

\section{Introduction}

The current safety architecture of the German fire brigades nowadays is based in part on fire tests from the year 1939 [1] yet. However, modern home furnishings 
realistically have a much higher fire load than 80 years ago and it is well known that fires with a high ratio of plastics involved show a different behavior than fires with predominantly ligneous materials. To that effect, special attention was to be paid to the furnishings.

The investigation of fires in individual rooms has been the subject of numerous research projects. The works of DiNenno [2] and Drysdale [3] can be named as standard works. However, the smoke spread between rooms of a dwelling is not considered there. In [1] Robert and Ingbergexamined smoke spread in a furnished room. The fire load consisted of materials typical at that time such as wood and paper. Modern materials, as they are to be found in today's dwellings, were not considered thereby.

Moreover, experience shows that fire victims found in dwellings rather died from smoke intoxication than from thermal exposure [4] [5]. Hence, characterizing smoke migration, especially in terms of location of the smoke layer and the velocity of its spread from the room of the initial fire to the adjacent rooms, should allow an improved assessment of time windows available for self-rescuing.

As part of a national research assignment, two full-scale fire tests were carried out in an abandoned building. Among other things, the motivation was to execute fire scenarios in fully-equipped apartments and not only in a single room fire.

The focus was on a set of furniture, electric appliances and materials which corresponded to modern apartment fires and allowed conclusions on a horizontal spread of fire and smoke spreading in such apartments.

In the two fire tests, the fire evolution observed was different though all conditions in terms of layout of the apartments, fire load distribution, ignition conditions, etc. were equal. The first test one did not develop into a self-sustained fire propagation. Instead, the fire, initiated in the (open) kitchen, only spread to the living room and then tended to suffocate until a window was deliberately destroyed to allow access to fresh air.

In the second test, the fire developed freely without being influenced from outside. The present report therefore is focused more on the second fire test.

\section{Experimental Setup and Apartment Layout}

\subsection{Fire Apartments}

The large-scale fire tests comprehended two intentional fire events in an uninhabited dwelling house in Weißwasser, Germany on the $11^{\text {th }}$ of April 2013. Therefore two apartments with four rooms each inside a five-story dwelling house were fully furnished and instrumented with a variety of fire monitoring sensors as described below. During the test all data were recorded by temperature data loggers and rooms were monitored by a camera system. Furthermore all live information was streamed to a control center outside the building. 
The dwelling house had a pre-cast reinforced concrete skeleton structure with five floors and an inner staircase. On every floor two apartments were available, a two-room apartment on the left hand and a four-room apartment on the right hand. The experiments reported here took place in the four-room apartments.

The apartment for the second fire tests was located in the third floor about in the middle of a dwelling complex of buildings (Figure 1). The living room faced southeastwards and the sleeping rooms faced northwestwards. The main corridor was the main connection to all rooms and the staircase. The apartment had a living room connected with an open kitchen and a balcony. Next to the kitchen was the bathroom and adjacent to this the bedroom, both were reached from the main corridor. There was no inner door from the kitchen to the main corridor as well as the main corridor to the small corridor. Over the small corridor the home office and the nursery could be reached.

\subsection{Fire Load}

For the furniture, the apartment was equipped with, it was important to match realistic conditions. Therefore special emphasis was given on contemporary residential furniture, including a mixed fire load, which represents the contemporary ratio of plastics and wooden materials.

That means, that the residential furniture implied ligneous furniture as well as electrical devices (e.g. TV set, computer, laptop, etc.), objects with high ratio of polymers (e.g. upholstery, plastic shelf or decoration) plus clothes, blankets and so on made of synthetics.

The number of electrical devices such as tv-sets and computers was based on data given by the German Federal Statistical Office [6]. Current consumer catalogues and sale products were used as guides for the selection of the materials of the furniture and other objects also.

The literature values of fire load densities for a dwelling range from 495 $\mathrm{MJ} / \mathrm{m}^{2}$ [7] up to $1145 \mathrm{MJ} / \mathrm{m}^{2}$ [8]. So the data of the CIB W14 Workshop Report (1983) [9] and the current DIN EN 1991-1-2: NA [10] give a usable average with $780 \mathrm{MJ} / \mathrm{m}^{2}\left(234 \mathrm{MJ} / \mathrm{m}^{2}\right.$ standard deviation), which was used as a guiding value to equip the test apartment.

The fire load calculation is based on the well-known formula from [11] [12]

$$
Q^{\prime \prime}=\frac{\sum M_{i} \cdot H_{c, i} \cdot \chi_{i}}{A}
$$

To execute the fire load calculation, it was necessary to weigh every single subject. The heat of combustion for the various combustible materials was predominantly taken from international literature. For this reason, the opportunity was given to utilize the international combustion efficiency for the fire load calculation. The values for the heat of combustion were taken from the following references [9] [11]-[22]. Table 1 shows the floor area and fire load density of the experimental apartment. Overall, the fire load reached a value of $\mathrm{Q}=44,694.6$ MJ. With an apartment ground area of about $68.3 \mathrm{~m}^{2}$ the fire load density 


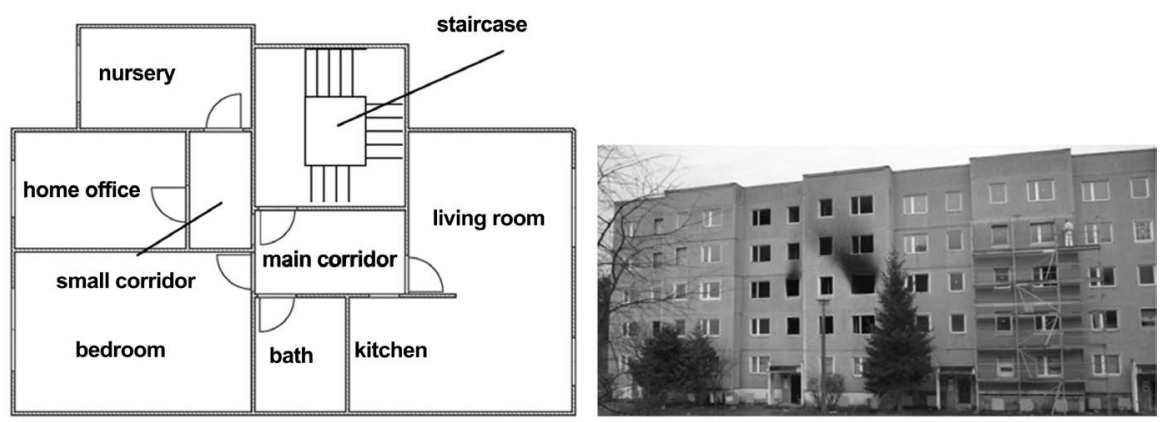

Figure 1. Apartment layout and dwelling complex. View of northwest front with burning marks at the bedroom and nursery window.

Table 1. Fire load density with ground area.

\begin{tabular}{ccc}
\hline Room & $\mathrm{m}^{2}$ & $\mathrm{MJ} / \mathrm{m}^{2}$ \\
\hline Livingroom & 18.3 & 695.9 \\
Kitchen & 5.5 & 1106.3 \\
Maincorridor & 6.3 & 324.4 \\
Bedroom & 14.4 & 676.4 \\
Smallcorridor & 3 & 496.9 \\
Homeoffice & 9.6 & 690.4 \\
Nursery & 7.9 & 732.8 \\
Apartment & 68.3 & 654.6 \\
\hline
\end{tabular}

reached a value of $654.6 \mathrm{MJ} / \mathrm{m}^{2}$. So the fire load density took a value that is in the average range for a dwelling and constitutes a representative value. The bathroom was left out of the furniture because of the usually minor fire load.

The present mixed fire load can be simplified into two material categories: ligneous and plastics. The category of ligneous objects and furniture includes solid wood and wood composite materials as well as cellulosic materials, such as books, and natural textile materials like cotton. The plastics category contains all objects and furniture with a predominant amount of synthetic or semi-synthetic plastics (e.g. upholstery, electrical devices and clothing made of synthetic fibers). Table 2 shows the proportion of each in relation to the entire apartment and the particular rooms.

The arrangement of furniture of all rooms is shown basically in Figure 2. The closets, bookcases, shelves and storage racks were filled or fitted with objects according to their normal use.

In the wall unit in the living room, electrical appliances, such as DVD player or radio were located, in addition to magazines and books, but also videotapes and small packs of tablecloths and other decorative items. The closets and shelves in the two corridors were filled with shoes and clothing as well as books, magazines and electronic equipment. 
Table 2. Ratio of combustible material condition.

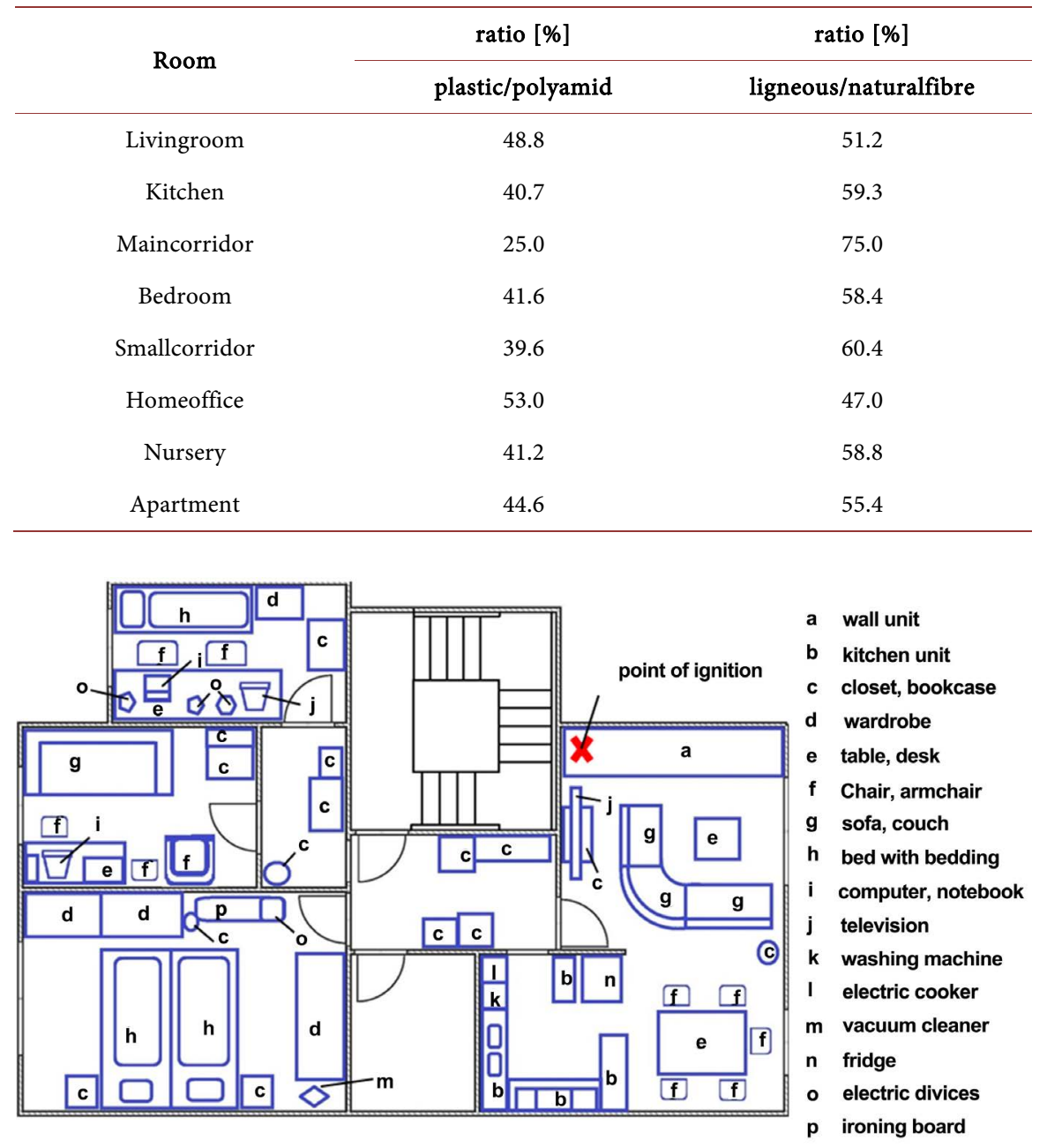

Figure 2. Plan view of experimental apartment showing furniture layout.

In the bedroom, the wardrobe and the double bed were the main fire load. The wardrobes were fully stocked with shoes, clothes and other garments of different materials. Electrical devices such as a radio and a vacuum cleaner were also present in the bedroom. The home office was characterized by a very high plastics content. Especially the furniture of a home office with all appropriate technical devices and computer equipment plus a guest bed and other upholstery formed the base. The bookcases were mostly filled with books and magazines. The fire load in the nursery combined parts from the home office and the bedroom. Closets and shelves were filled with laundry as well as books and decorative items. The bed and the television, plus computer equipment supplied the main plastic components.

The floor covering mainly consisted of PVC flooring originating from the eighties of last century when the building was erected. In the living room, bedroom and nursery and in the main corridor carpets were installed additionally. Wall papers were also glued to all walls. Ceiling panels made of polystyrene were 
attached at the ceilings of the two-apartment corridor (small and main corridor). All other ceilings remained free of attached materials.

\subsection{Ventilation}

Ventilation conditions generally have a significant impact on an event of fire. The fire is mostly well-ventilated in the growth phase, but when it spreads in a closed environment (room, apartment) the fire can become ventilation-controlled soon. For ventilation-controlled fires, a predominantly incomplete combustion can be assumed, which also reduces the heat release rate [11].

In the full-scale fire test conducted the initial conditions were chosen as follows: All inner doors were fully open, except the bathroom door. The apartment door (main entrance door) was fully closed. The casement of the big ground-level window (balcony door) in the living room was hinged. The large casement in the bedroom of the window and the window in the nursery were also bottom hinged. The initial conditions are depicted in Figure 3.

The meteorological data for the test day ( $11^{\text {th }}$ April 2013) shows that between the hours $2 \mathrm{pm}$ and $6 \mathrm{pm}$ the humidity was from 63\% to 77\% with a wind movement of $5 \mathrm{~m} / \mathrm{s}$ to $9 \mathrm{~m} / \mathrm{s}$. During the period under observation, no rain fell. The ambient temperature ranged between $11^{\circ} \mathrm{C}$ and $14^{\circ} \mathrm{C}$. Before ignition, the air temperature in the test apartment was about $15^{\circ} \mathrm{C}$ in all rooms.

\subsection{Instrumentation}

To monitor the temperatures during the fire test, mineral insulated thermo couples $\mathrm{NiCr}-\mathrm{Ni}$ type $\mathrm{K}$ was installed on various places in the apartment (see Figure 4). Sixteen thermocouple trees held two thermocouples each and were installed at a height of $0.7 \mathrm{~m}$ (named "a") and $1.8 \mathrm{~m}$ (named "b") above the floor level. The thermocouples in the living room, kitchen and bedroom were connected with a data logger Agilent 34,972 A which was placed in the neighboring apartment. This data logger works with a frequency of $0.33 \mathrm{~Hz}$. The thermocouples in the small corridor, home office and nursery were directed through the wall into the next apartment. There was another data logger placed which worked with a frequency of $1 \mathrm{~Hz}$.

A gas measuring probe was also installed in the room of ignition (see Figure 4), at a height of about $0.8 \mathrm{~m}$ gas samples were extracted continuously and were transported through a heated pipe system to the measuring equipment. The concentration of carbon dioxide, carbon monoxide and oxygen were recorded.

Several network cameras were also used to monitor the fire development and fire spread. In every room a CCTV camera for the video documentation of the fire test was installed. All camera time stamps and data logger clocks had been synchronized prior to ignition.

To measure the smoke spread, a qualitative method was chosen. A grid was sprayed onto the walls, so that the height of the smoke layer in a room could be read via the video documentation. 


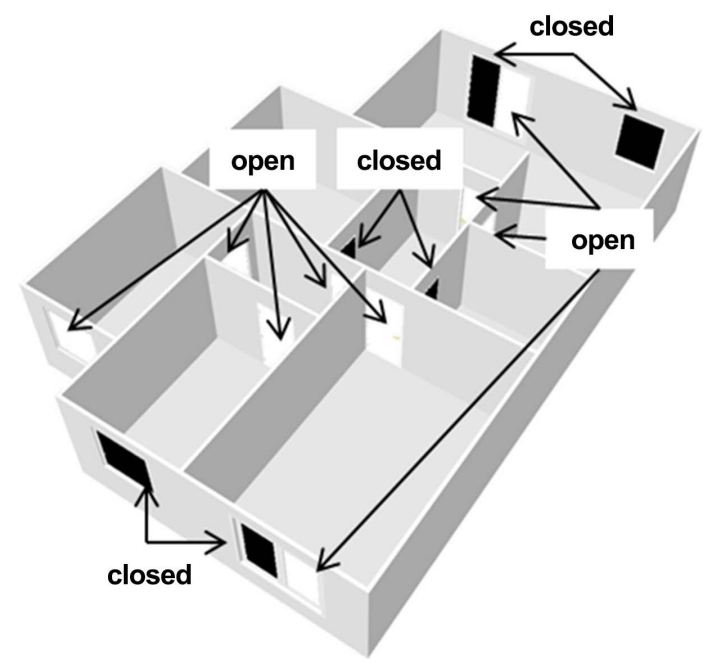

Figure 3. Initial ventilation conditions for full-scale fire test (test two).



Figure 4. Plan view of experimental apartment showing positions of thermocouples, cameras and gas measuring point.

\section{Fire Test Progress and Results}

At first the test procedure will be described below by the fire growth phase. The first major event is chosen to describe the effects of the area of initial fire to other rooms of the apartment. After this, the smoke spreading and the horizontal fire spread in the apartment will be analyzed.

The test took place on the 11 $1^{\text {th }}$ April At 15:58:12 BBQ charcoal lighter (solid) was ignited to mock a defect in an electrical device in the wall unit (living room). The ignition source was placed on the left side of the wall unit (left corner, next to the staircase, see Figure 2) on a shelf element on medium height. Next to the ignited $\mathrm{BBQ}$ charcoal lighters, there were a lot of decoration materials, small place mat, books, etc.

\subsection{Temperature Profile of the Hot Gas Layer in the Roll-Over Event}

The description of the hot gas layer is related to the thermocouples in a height of $1.8 \mathrm{~m}$ (above floor) only. 
At 16:00:49, 1 min $37 \mathrm{~s}$ after the ignition of the BBQ charcoal lighter, black smoke rose out of the shelf and reached the ceiling above the wall unit. About 16:04:57 (405 s) the first tongues of flames were spotted along the ceiling. Already $390 \mathrm{~s}$ (16:11:27) later, the flames spread until the middle of the living room ceiling and the fire spread forward across the wall unit. At 16:12:35 (863 s) the hinged casement of the big ground-level window (balcony door) failed because the rubber profile of the window glass was thermally processed so that the window glass fell inside. Because of the resulting opening, hot combustion gases could escape out of the room. In the time-temperature graph (Figure 5) an obvious decline about $50 \mathrm{~K}$ is visible. The television was on fire at 16:14:51 (999 s) and $16 \mathrm{~s}$ later $(16: 15: 07,1015 \mathrm{~s})$ the arm rest of the sofa began to burn. Thus, the temperature rose in the fire room again and reached at 16:14:59 (1050 s) temperatures around $190^{\circ} \mathrm{C}$ already.

During the further progress of the fire, there was a very strong and rapid temperature increase by the ignition of the fumes in the living room (roll-over event).

The period of the roll-over includes the sharp rise in the temperature and the gas ignition of the fumes. In the experiment the roll-over took place between the period from 16:14:22 (1011 s) to 16:19:41 (1344s). After this duration the temperature dropped very quickly to values of about $200^{\circ} \mathrm{C}$.

Within $3 \mathrm{~min}$ and $36 \mathrm{~s}$ (to 16:18:27 (1266 s)) the thermocouple 1.2 recorded values above $800^{\circ} \mathrm{C}$ during a time of $72 \mathrm{~s}$. The thermocouple 1.1, which was located between wall unit, sofa and balcony door, and the thermocouples 1.3, that was positioned between the living room sofa and table (see Figure 4), recorded a temperature rise to more than $800^{\circ} \mathrm{C}$ at $16: 18: 47$ (1287 s) for about $78 \mathrm{~s}$.

It is noticeable that the thermocouple 1.4, in the time duration from 16:18:27 (1266 s) to 16:20:02 (1365 s), didn't reach the temperatures of the other thermocouples. The measurements remained below $600^{\circ} \mathrm{C}$. This is mainly attributable to the facts that the thermocouple 1.4 hung near a hinged window and the flaming spread of the roll-over didn't reach this part of the living room entirely.

Figure 6 shows the temperature profiles in the living room in a height of 1.8 $\mathrm{m}$, from the time of ignition at 15:58:12 (0 s) until the end of the test at 18:16:45 (8664 s). Due to a defective cable of the mineral insulated thermo couple the measuring point 1.5 sent values to $16: 17: 23$ only, then the series of measurements of these thermocouples broke off.

In the kitchen the temperature increased about $250 \mathrm{~K}$ by the sudden rise of the temperature during the roll-over in the living room. That means that the hot gas layer from the living room reached the kitchen at 16:19:41 (1344 s) so that there were temperatures of approximately $400^{\circ} \mathrm{C}$ (see Figure 4 and Figure 5).

The rapid expansion of the hot gas layer between the living room and kitchen is mainly to be explained that the two rooms were connected to each other by an opening. So the hot combustion gases could flow along the ceiling from the living room to the kitchen without any obstruction (no door lintels, beams etc.). 


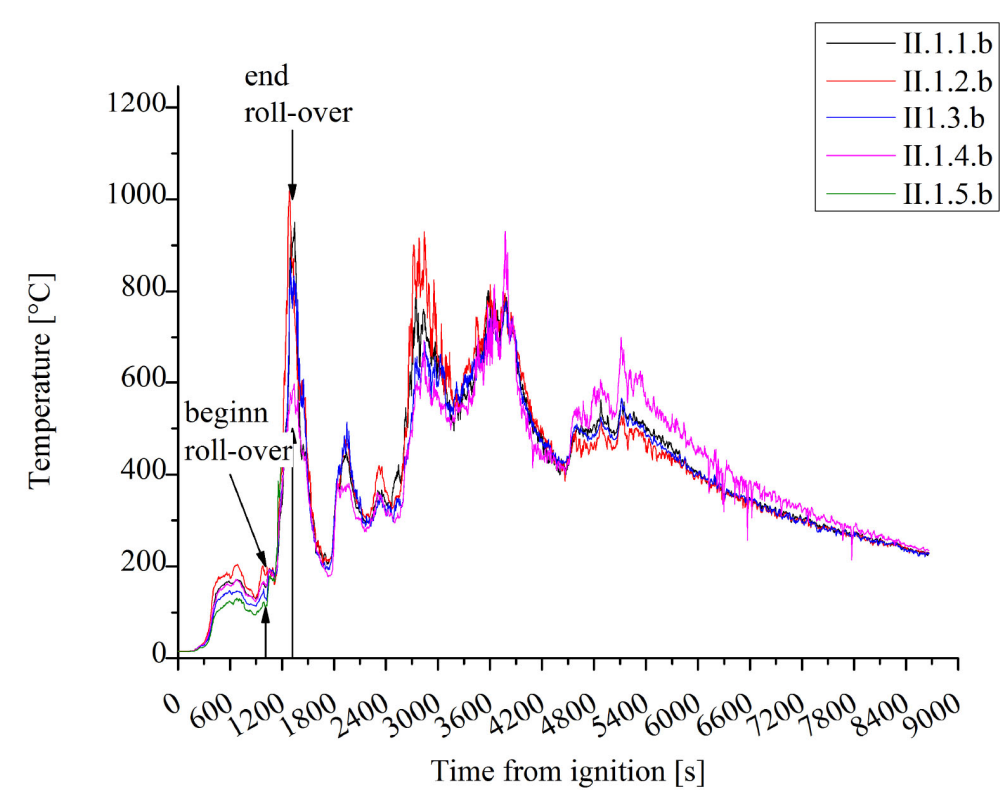

Figure 5. Time-temperature curves of the hot layer gas in the living room (height 1.8. m).

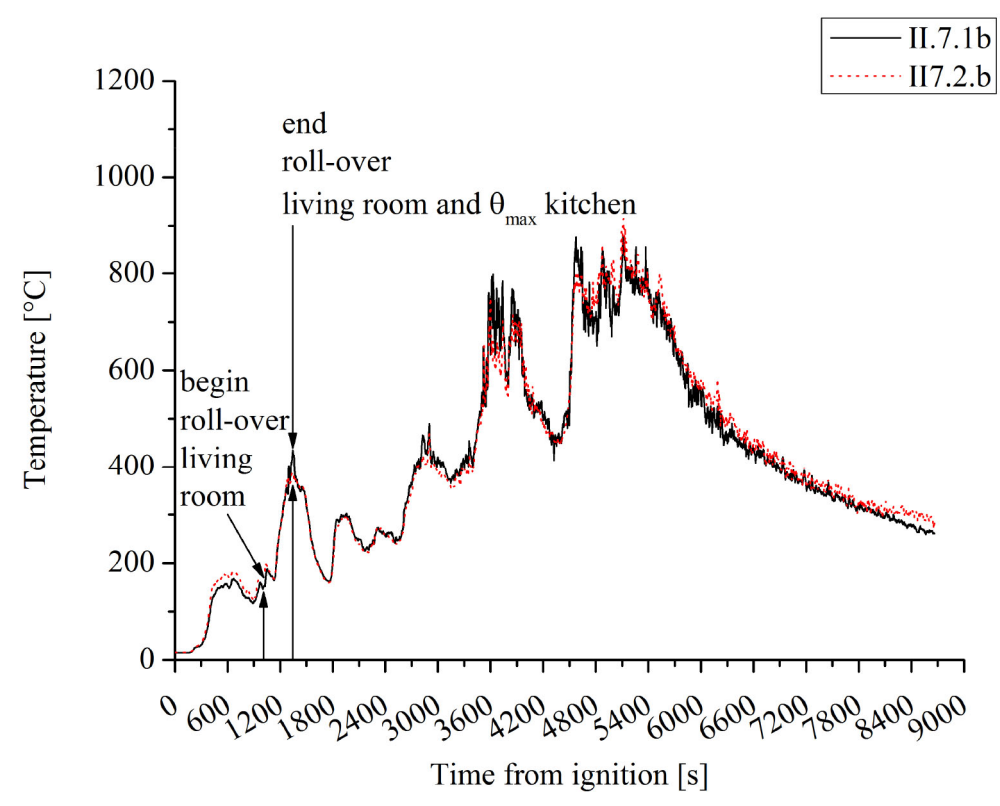

Figure 6. Time-temperature curves of the hot layer gas in the kitchen (height $1.8 \mathrm{~m})$.

The roll-over affected also the main corridor with a very short delay in the temperature rise. This could be due to the door lintel which obstructed the hot gas layer to flow into the main corridor from the living room. But the delay is so marginal that the roll-over in the living affected the main corridor directly (see Figure 7).

Also the bedroom was affected directly by the roll-over in the living room. There was an increase of the temperature in the hot gas layer of about $130 \mathrm{~K}$. 


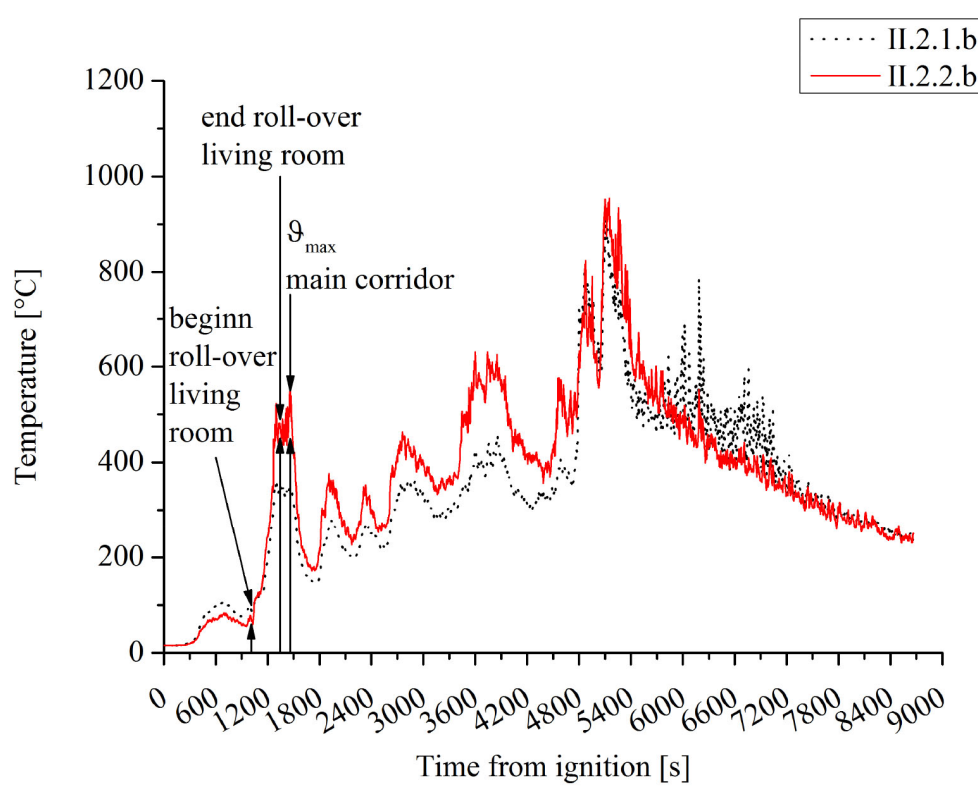

Figure 7. Time-temperature curves of the hot layer gas in the main corridor (height $1.8 \mathrm{~m}$ ).

The maximum temperature of $177^{\circ} \mathrm{C}$ was reached in $1491 \mathrm{~s}(16: 22: 03)$ after the ignition of the wall unit. So the roll-over peak in the living room needed $2 \mathrm{~min}$ and $27 \mathrm{~s}$ to cause an independent temperature peak in the bedroom (Figure 8).

During the time of the roll-over in the living room the temperature in the small corridor, home office and in the nursery rose for about 70 to $80 \mathrm{~K}$. In the home office and in the nursery a temperature maximum of up to $100^{\circ} \mathrm{C}$ was recorded. The temperature in the small corridor was about $126^{\circ} \mathrm{C}$ (see Figures 9(a)-(c)). It shows that the roll-over event in the living room had a direct effect on all these rooms and caused a temperature rise plus a constant temperature level beyond the period of the roll-over.

Table 3 shows an overview of the maximum temperature values and their occurrence during the roll-over period (1011 s to $1344 \mathrm{~s}$ ).

The previously mentioned facts show that a fire phenomenon in a burning room, like a roll-over, has a direct effect on other rooms in an apartment. It shows that a rapid temperature rise spreads through the whole apartment and results also in a temperature rise in adjacent rooms. Particular ventilation conditions could also result in an additional temperature maximum beyond the period of the fire phenomenon, seen in the temperature profiles of the main corridor and of the bedroom.

\subsection{Smoke Spreading}

Smoke is one of the most hazardous aspects for humans in an event of fire. Especially in the growth period of the fire the smoke movement has a significant meaning. For the human safety it is important to know when the smoke reaches and fills the rooms next to the fire room in an apartment. 


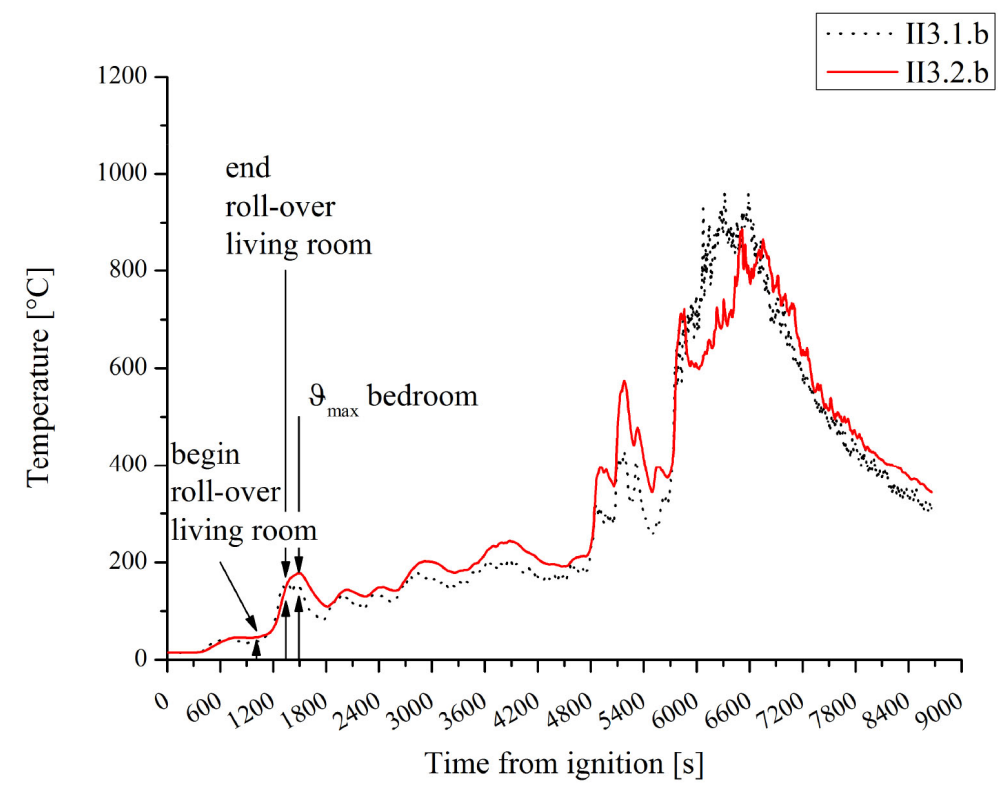

Figure 8. Time-temperature curves of the hot layer gas in the bedroom (height $1.8 \mathrm{~m}$ ).

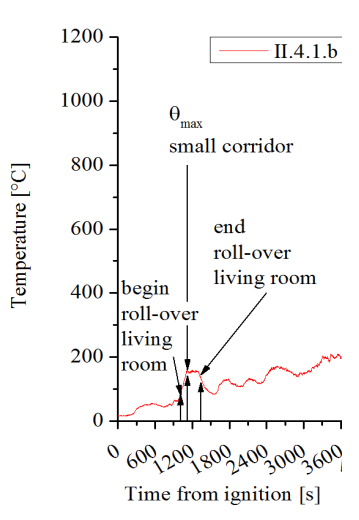

(a) Small corridor



(b) Home office

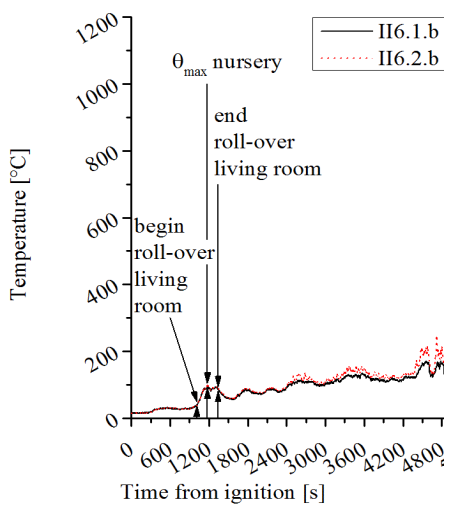

(c) Nursery

Figure 9. Temperature-time curves of the hot layer gas in the small corridor, home office and nursery (height $1.8 \mathrm{~m}$ ).

Therefore the smoke spreading of the full-scale fire test is described and some general conclusions are derived. The following conclusions of the smoke spreading are based on the camera recordings. Because of the ventilation conditions sometimes it was very difficult to make an explicit analysis of the smoke spreading. Especially monitoring when the smoke layer reached a defined mark or the floor level was difficult because of the turbulent conditions in the test apartment (see ventilation). So the evaluation of the video documentations for the level of low-smoke layers is a qualitative determination.

Hence, it was defined that a certain mark was reached by smoke if a smoke formation reached the first time a mark visually. A solid smoke layer formation was not a criterion because a full development of a clearly distinguishable smoke layer was often not possible by the present turbulence. 
Table 3. Maximum temperature during the roll-over period in adjacent rooms.

\begin{tabular}{ccccc}
\hline Room & Thermocouple & $\mathcal{\vartheta}_{\max }\left[{ }^{\circ} \mathrm{C}\right]$ & $\begin{array}{c}\text { Test time } \\
{[\mathrm{hh}: \mathrm{mm}: \mathrm{ss}]}\end{array}$ & $\begin{array}{c}\text { Time from ignition } \\
{[\mathrm{s}]}\end{array}$ \\
\hline \multirow{2}{*}{ Kitchen } & $7.1 . \mathrm{b}$ & 435 & $16: 19: 41$ & 1344 \\
& $7.2 . \mathrm{b}$ & 387 & $16: 19: 41$ & 1344 \\
Maincorridor & $2.1 . \mathrm{b}$ & 365 & $16: 18: 58$ & 1299 \\
& $2.2 . \mathrm{b}$ & 548 & $16: 21: 34$ & 1461 \\
Bedroom & $3.1 . \mathrm{b}$ & 156 & $16: 20: 22$ & 1386 \\
Smallcorridor & $3.2 . \mathrm{b}$ & 177 & $16: 22: 04$ & 1491 \\
\multirow{2}{*}{ Homeoffice } & $4.1 . \mathrm{b}$ & 161 & $16: 16: 09$ & 1123 \\
& $5.1 . \mathrm{b}$ & 105 & $16: 15: 51$ & 1166 \\
Nursery & $5.2 . \mathrm{b}$ & 99 & $16: 16: 54$ & 1169 \\
& $6.1 . \mathrm{b}$ & 95 & $16: 17: 01$ & 1177 \\
\hline
\end{tabular}

Already at 16:00:58 (00:02:46) the smoke layer pulled down to the mark $2 \mathrm{~m}$ in the living room. At 15:59:34, $1 \mathrm{~min} 22 \mathrm{~s}$ after ignition, smoke streamed into the area of the kitchen. The bedroom camera showed after $183 \mathrm{~s}$ smoke was entering from the living room into the main corridor and spread towards the bedroom.

At 16:01:50 (00:03:38) the height of the low-smoke layer in the kitchen was below $1.50 \mathrm{~m}$, but in the connected living room the mark of $1.50 \mathrm{~m}$ hadn't yet been reached, that was after almost about $20 \mathrm{~s}$ later (00:03:54). The smoke layer limit in the bedroom was already at 16:02:42 (00:04:30) below $2.0 \mathrm{~m}$. Smoke came out from the tilted bedroom window at 16:03:07 (00:04:55).

Table 4 shows the time duration after ignition and when the height of the low-smoke layer had reached the mark of $2.0 \mathrm{~m}, 1.5$ and $1.0 \mathrm{~m}$ above floor level plus floor level itself.

Due to the predominant flow conditions, the boundary between the smoke layer and low-smoke layer is not definitely allocable by the video documentations. Especially in the nursery, it was observed that when the smoke streamed into the room, it fell down in the entrance area, so that the ground level was reached after $332 \mathrm{~s}$ already but not in every part of the room.

With the values of Table 4 it is possible to make a conclusion about the velocity of the smoke spreading in an apartment. An important fact that has to be taken into account is the influence of the door lintel which can be different in every apartment, because the door lintel stops the smoke to move into the next room initially. So the area over the door lintel must filled up with smoke until the smoke spreading can be continued through the door into the next room.

Therefore it's significant that the following conclusion comprehend a door lintel of $0.6 \mathrm{~m}$ (vertical distance between ceiling and doorway) for every inner door and opening. For a better traceability Table 5 shows the volumes of the ceiling areas that have to be filled with smoke before the smoke was able to move into another room theoretically. 
Table 4. Documented smoke spreading.

\begin{tabular}{|c|c|c|c|c|c|c|}
\hline & Living room & Kitchen & Main corridor & Bedroom & Home office & Nursery \\
\hline Window & open & - & - & open & closed & open \\
\hline \multirow{2}{*}{ Enter room } & \multirow{2}{*}{ ignition room } & $82 \mathrm{~s}$ & $183 \mathrm{~s}$ & $228 \mathrm{~s}$ & $238 s$ & 243 \\
\hline & & $15: 59: 34$ & $16: 01: 15$ & $16: 02: 00$ & $16: 02: 10$ & $16: 02: 15$ \\
\hline \multirow{2}{*}{$2 \mathrm{~m}$} & $166 \mathrm{~s}$ & $164 s$ & $223 \mathrm{~s}$ & $270 \mathrm{~s}$ & $313 \mathrm{~s}$ & $326 \mathrm{~s}$ \\
\hline & $16: 00: 58$ & $16: 00: 56$ & $16: 01: 55$ & $16: 02: 42$ & $16: 03: 25$ & $16: 03: 38$ \\
\hline \multirow{2}{*}{$1.5 \mathrm{~m}$} & $234 \mathrm{~s}$ & $218 s$ & $294 \mathrm{~s}$ & $312 \mathrm{~s}$ & $328 \mathrm{~s}$ & \multirow[b]{2}{*}{ - } \\
\hline & $16: 02: 06$ & $16: 01: 50$ & $16: 03: 06$ & $16: 03: 41$ & $16: 03: 40$ & \\
\hline \multirow{2}{*}{$1 \mathrm{~m}$} & \multirow[b]{2}{*}{ - } & $260 \mathrm{~s}$ & $344 s$ & $329 \mathrm{~s}$ & $364 s$ & \multirow[b]{2}{*}{-} \\
\hline & & $16: 02: 22$ & $16: 03: 46$ & $16: 03: 41$ & $16: 04: 16$ & \\
\hline \multirow{2}{*}{ Ground level } & $331 \mathrm{~s}$ & $273 \mathrm{~s}$ & $364 \mathrm{~s}$ & $355 \mathrm{~s}$ & $377 \mathrm{~s}$ & $332 \mathrm{~s}$ \\
\hline & $16: 03: 43$ & $16: 02: 45$ & $16: 04: 16$ & $16: 04: 07$ & $16: 04: 29$ & $16: 03: 44$ \\
\hline
\end{tabular}

Table 5. Ceiling volume above door lintel.

\begin{tabular}{cccc}
\hline Room & Living room \& kitchen & Main corridor & Small corridor \\
\hline Volume $\left[\mathrm{m}^{3}\right]$ & 14.28 & 3.78 & 1.8 \\
\hline
\end{tabular}

Combined with the distance between the point of ignition and entrance area of every room plus the time duration of the inflow of each room the horizontal velocity of the smoke spreading in an apartment can be calculated. Figure 10 shows the distances that are the basis of the calculation.

The results (Table 6) show that in the growth period of an apartment fire the smoke spreads with an average velocity from 0.02 to 0.04 meters per second. Particularly for rooms which are the room after the next to the area of fire, the average velocity for the smoke spreading is a good estimation and it is possible to do an engineering approach to forecast the smoke spreading in an apartment for human risk analyses.

The same values for the average velocity of smoke spreading were monitored as well as in the other full-scale apartment fire test (test one) which was carried out in the same building. Important to know is that in fire test one all windows of the four room apartment were closed. So it is possible to conclude that the performed value of smoke velocity is generally applicable for an apartment fire in the growth period independent of the initial ventilation conditions (open or closed windows).

\subsection{Horizontal Fire Spread}

The progress of the development of a fire spread depends on various factors. These factors include the type and quantity of combustible materials, the distribution of the fire load and the ventilation conditions in the fire room [25] [26]. Typical stages of development for fires where no fire fighting intervention takes place are the incipient fire, growth period, fully developed fire (burning) and the decay phase (see Figure 11)

The typical fire development is characterized by a rapid and strong temperature increase with temperature values up to $1000^{\circ} \mathrm{C}$ between the growth period and the fully developed fire (burning). 




Figure 10. Plan view of the distance between the point of ignition and entrance of each room.

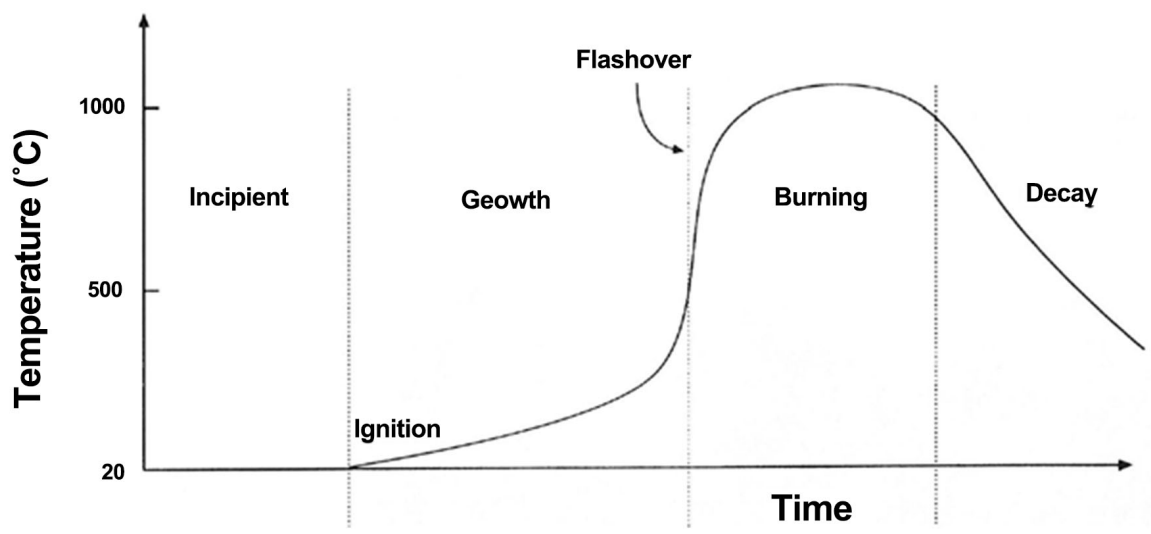

Figure 11. Typical fire development curve [23] [24].

Table 6. Average velocity of smoke spreading.

\begin{tabular}{cc|cccccc}
\hline \multicolumn{2}{c}{ Smoke spreading } & Kitchen & Main corridor & Bedroom & Home office & Nursery \\
\hline \multirow{2}{*}{ Enter room } & Time $[\mathrm{s}]$ & 82 & 183 & 228 & 238 & 243 \\
& Velocity $[\mathrm{m} / \mathrm{s}]$ & 0.056 & 0.017 & 0.028 & 0.032 & 0.036 \\
\multirow{2}{*}{$\begin{array}{c}2 \mathrm{~m} \text { mark } \\
\text { (over floor) }\end{array}$} & Time $[\mathrm{s}]$ & 164 & 223 & 270 & 313 & 326 \\
\hline
\end{tabular}

The typical fire development curve can also be seen in the time-temperature curves from the present full-scale fire test. Thereby, a qualitative assessment is possible to determine that a room is burning, if the characteristic stages of fire development will be compared with the temperature-time curves (thermocouples in a height of 0.7 above floor) of the tested rooms.

A special fire phenomenon during the test was the roll-over in the living room. During the roll-over temperatures up to $1000^{\circ} \mathrm{C}$ were reached, but in the further course the temperatures fell quickly to values below $200^{\circ} \mathrm{C}$. For this reason a typical burning stadium (fully developed fire) wasn't reached in this 
stage of fire development yet. The fully developed fire phase was reached only after further horizontal fire spread at $2606 \mathrm{~s}$ after ignition (16:41:38).

The time-temperature graph (Figure 12) shows, that the temperature rose faster at thermocouple 1.2 and was initially higher than the other thermocouples. The temperature rise was caused by the burning wall unit and sofa, which were placed next to the thermocouple 1.2. At 16:57:48 (3576 s) the table and chairs in the dining area of the living room began to burn (see Figure 2) which resulted that the temperature increased about $400 \mathrm{~K}$ at the thermocouple 1.4.

The phase of the fully developed fire was reached at 17:11:35 (4403 s) in the kitchen (see Figure 13(a)). One minute later the main corridor also reached the fully developed fire phase (see Figure 13(b)). The bedroom reached the fully developed fire phase as the last at (Figure 14).

The fire spread didn't reach the other rooms of the apartment, so that no fully developed fire phase occurred.

For the representation of the horizontal fire spread from room to room, on the basis of the fully developed fire phase, the average mean temperature $\vartheta_{\text {mid,0.7 }}$ was calculated. $\vartheta_{\text {mid, } 0.7}$ is calculated as the average of the individual thermocouples, which were located in each room at a height of $0.7 \mathrm{~m}$.

In Figure 14 the average mean temperature $\vartheta_{\text {mid } 0,7}$ is shown for each room. The intersections of the curves mark the spread of fire into another room.

The temperature profiles of a room end if in the adjoining room $\vartheta_{\text {mid, } 0.7}$ has higher values. In Figure 14 it is apparent, that during the fully developed fire in the kitchen also the main corridor started with this stage of fire only with a little delay.

For the beginning of the fully developed fire phase in every room, the following time can be taken.

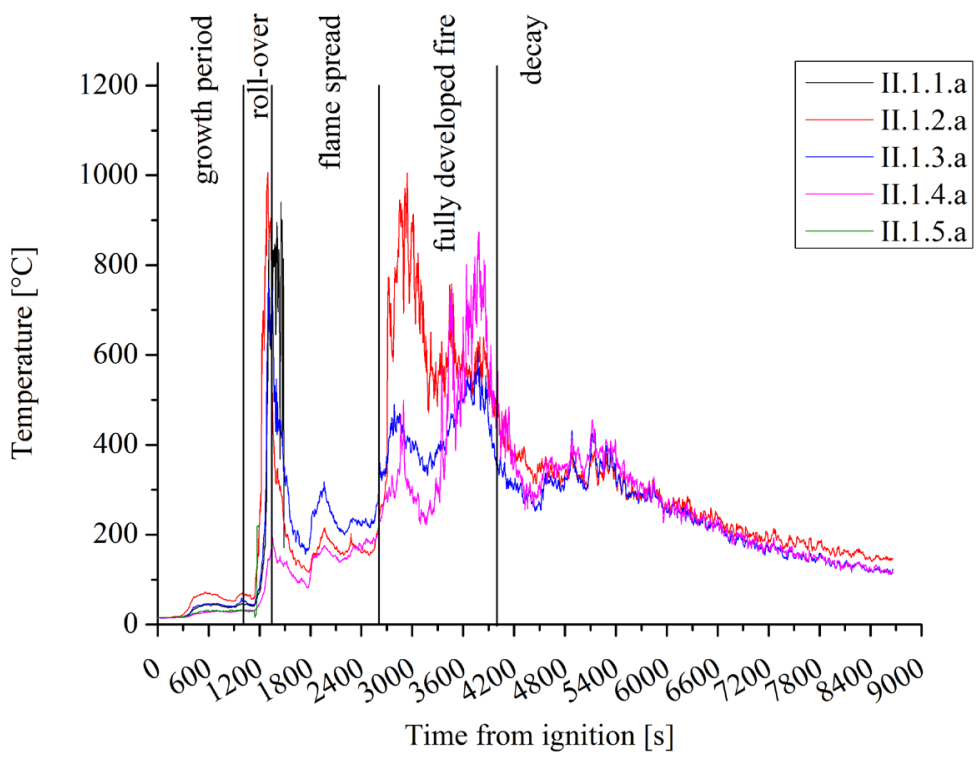

Figure 12. Stages of fire development in the living room. 


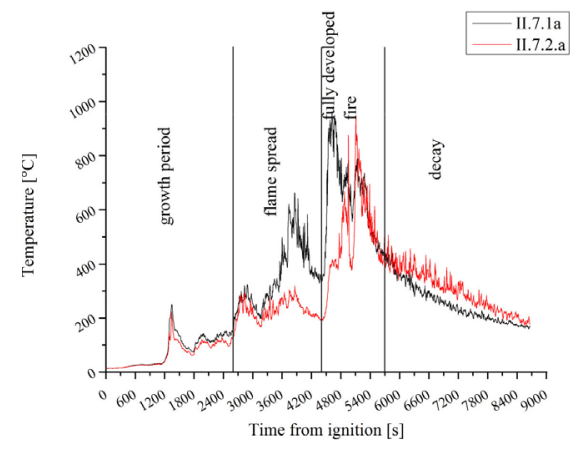

(a) Kitchen

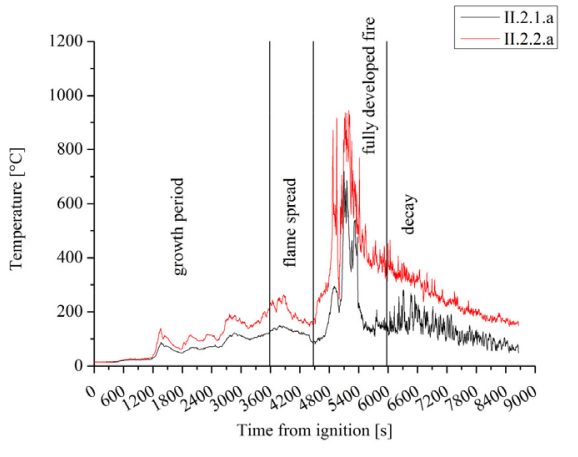

(b) Maincorridor

Figure 13. Stages of fire development in the kitchen (a) and main corridor (b).

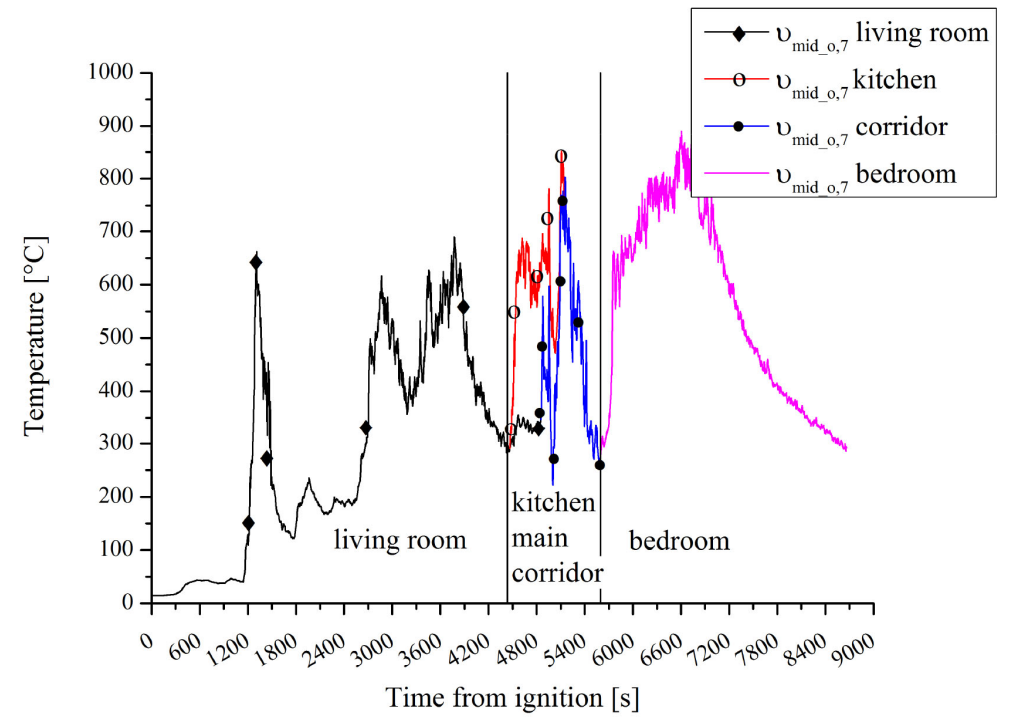

Figure 14. Fully developed fire phase in all rooms.

- Livingroom 16:14:36 (2604 s).

- Kitchen 17:12:39 (4467s).

- Maincorridor 17:19:06 (4854s).

- Bedroom 17:31:27 (5595s).

Thereby, $15 \mathrm{~min}$ and $48 \mathrm{~s}$ after the ignition the living room was fully burning and $58 \mathrm{~min}$ and $3 \mathrm{~s}$ later, in the kitchen was a fully developed fire. After further 6 $\min$ and $45 \mathrm{~s}$ the fire in the main corridor was fully developed. Because of the fire in the main corridor, after further $12 \mathrm{~min}$ and $35 \mathrm{~s}$ the bedroom reached the fully developed fire phase.

\section{Conclusions}

To investigate how the smoke spreads in an apartment, a 4-room apartment was fully furnished with combustible items corresponding to nowadays mixtures of materials and to a fire load representing an average level of energy stored per ground area for housing. Through the furniture, a mixed fire load was formed. The fire load of the apartment was divided into two material categories: 
- ligneous objects and furniture (solid wood, wood composite materials, cellulosic materials, books, cotton).

- plastic category (upholstery, electrical device and clothing made of synthetic fibers).

The smoke spread was observed with a camera system. In addition, the temperature was recorded at various points in the rooms. To measure the carbon dioxide, the carbon monoxide and oxygen concentration in the room of ignition gas samples were sucked out continuously and were transported through a heated pipe system to the measuring equipment.

During the experiment there was a very strong and rapid temperature increase by the ignition of the fumes in the living room (roll-over event). The roll-over took place between the period from 16:14:22 (1011 s) to 16:19:41 (1344 s). It could be shown that the temperature of the hot gas layer in the adjacent rooms also increased.

The horizontal velocities of the smoke spreading in an apartment were calculated. The results show that in the growth period of an apartment fire the smoke spreads with an average velocity from 0.02 to 0.04 meters per second. Hence, the smoke migrated much faster than the fire itself and filled all rooms of the apartment within a few minutes only. Thus, in the case under investigation even an incipient fire, if starting e.g. while the residents are sleeping, would have made self-rescuing through the corridors apparently impossible.

Interestingly, the smoke spread revealed to be strongly influenced by the door lintel which for some time contained the smoke layer in the room of the fire origin and thus decelerated the smoke migration.

Based on the temperature, which was set at a height of $0.7 \mathrm{~m}$ above the floor level, the horizontal fire spread could be displayed. The velocity of the horizontal fire spread was found to be moderate, such that response time of the fire department could be considered as effective for preventing fire spread to adjacent apartments or even structural failure of the load-bearing elements of the building.

Also for the fire brigade, the test provides interesting conclusions. Especially in the inside fire attack, it attaches importance to know that fire phenomena (e.g. roll-over in the area of fire) have impacts in all rooms of an apartment.

\section{Acknowledgements}

The project reported here was funded by the German Ministry of Education and Research in the framework "Safety for the civil society" (Project "TIBRO", Registration number 13N12176).

\section{Conflicts of Interest}

The authors declare no conflicts of interest regarding the publication of this paper. 


\section{References}

[1] Rodak, S. and Ingberg, S.H. (1967) Full-Scale Residential Occupancy Fire Tests of 1939. National Bureau of Standards Report 9527, Washington DC. https://doi.org/10.6028/NBS.RPT.9527

[2] Di Nenno, P. (2008) SFPE Handbook of Fire Protection and Engineering. 4th Edition, NFPA National Fire Protection Association, Quincy, MA.

[3] Drysdale, D. (2011) An Introduction to Fire Dynamics. Third Edition, Wiley, Hoboken, NJ. https://doi.org/10.1002/9781119975465

[4] You, K., Yang, H.T., Kym, D., Yoon, J., Yim, H., Cho, Y.S., et al. (2014) Inhalation Injury in Burn Patients: Establishing the Link between Diagnosis and Prognosis. Burns, 40, 1470-1475. https://doi.org/10.1016/j.burns.2014.09.015

[5] Yurt, R.W., Bessey, P.Q., Bauer, G.J., Dembicki, R., Laznick, H., Alden, N., et al. (2005) A Regional Burn Center's Response to a Disaster: September 11, 2001, and the Days Beyond. Journal of Burn Care \& Rehabilitation, 26, 117-124. https://doi.org/10.1097/01.BCR.0000155543.46107.E6

[6] Statistisches Bundesamt, Wirtschaftsrechnungen, Ausstattung privater Haushalte mit Gebrauchsgütern 2009, Fachserie 15 Reihe 2, Wiesbaden 2010.

https://www.destatis.de/GPStatistik/servlets/MCRFileNodeServlet/DEHeft derivate 00007409/2150200097004.pdf;jsessionid=AE64D1389D30BFAE428467653D57FBE $\underline{2}$

[7] Schweizerischer Ingenieur und Architektenverein, SIA 81 (1984) Brandrisikobewertung. Berechnungsverfahren, Zürich.

[8] Richard, W. and Bukowski, P.E. (2006) Determining Design Fires for Design-Level and Extreme Events. SFPE 6th International Conference on Performance-Based Codes and Fire Safety Design Methods, NIST Building and Fire Research Laboratory, Tokyo.

[9] National Institute of Standards and Technology (2009) Fire Fighting Tactics under Wind Driven Conditions. The Fire Protection Research Foundation, Quincy, MA.

[10] Deutsches Institutfür Normung e. V., DIN EN 1991-1-2/NA (2010) National Annex-Nationally Determined Parameters-Eurocode 1: Actions on Structures-Part 1-2: General Actions-Actions on Structures Exposed to Fire. Beuth Verlag, Berlin.

[11] Society of Fire Protection Engineers (2008) The SFPE Handbook of Fire Protection Engineering. 4th Edition, National Fire Protection Association, Quincy, MA.

[12] Kusche, C., Knaust, C. and Krause, U. (2013) Experimentelle Untersuchungen zur Verbrennungseffektivität als Grundlage für Brandlastberechnungen der DIN 18230. Bundesanstalt für Materialforschung und -prüfung (BAM) and Otto-von-Guericke-Universität Magdeburg, Berlin.

[13] Geiger, A. (1982) Ermittlung der aus der Sicht des Brandschutzes relevanten stoffspezifischen und toxischen Eigenschaften von Stoffen und Materialien, die bei der Herstellung von Wohnraummöbeln Verwendung finden, sowie Berechnung der Brandlast von Wohnung verschiedener Wohnungstypen mit durchschnittlichem Ausstattungsgrad, Abschlussarbeit, Fachhochschule des Ministeriums des Innern, Hermann Matern, Heyrothsberge.

[14] Steinleiter, H.-D. (1988) Brandschutz- und sicherheitstechnische Kennwerte gefährlicher Stoffe. Staatsverlag der Deutschen Demokratischen Republik, Berlin.

[15] Steinleitner, H.-D. (1979) Tabellenbuch brennbarer und gefährlicher Stoffe. Staatsverlag der Deutschen Demokratischen Republik, Berlin. 
[16] Babrauskas, V. (1980) Combustion of Mattresses Exposed to Flaming Ignition Sources Part II. Center for Fire Research National Engineering Laboratory, Washington DC. https://doi.org/10.6028/NBS.IR.80-2186

[17] Deutsches Institut für Normung e.V., DIN 18230-3 (2002) Baulicher Brandschutz im Industriebau-Teil 3. Beuth Verlag, Berlin.

[18] Zehfuß, J. and Hosser, D. (2002) Validierungsversuch mit Mobiliarbrandlasten im Rahmen des Forschungsvorhabens Theoretische und experimentelle Untersuchung zum erforderlichen Brandschutz bei mehrgeschossigen Gebäuden in Stahlbauweise. Institut für Baustoffe, Massivbau und Brandschutz (iBMB), Braunschweig.

[19] Blume, G.W. (2003) Ingenieurmodell zur brandschutztechnischen Bemessung von Bauteilen auf der Basis von experimentell ermittelten Verbrennungseffektivitäten. Dissertation, Technische Universität Carolo-Wihelmina zu Braunschweig, Braunschweig.

[20] Hou, J. (2011) Distribution Curves for Interior Furnitures on CO2, CO, HCN, Soot, and Heat of Combustion. Department of Civil and Natural Resources Engineering University of Canterbury, Christchurch, New Zealand.

[21] National Bureau of Standards (1984) Fire Performance of Furnitures As Measured in the NBS Furniture Calorimeter. Part I, U.S. Department of Commerce, Washington DC.

[22] Knaust, C. (2009) Modellierung von Brandszenarien in Gebäuden. Dissertation, Technische Universität Wien, Berlin.

[23] Hosser, D., et al. (2009) Leitfaden Ingenieurmethoden des Brandschutzes. Vereinigung zur Förderung des Deutschen Brandschutzes e.V., Braunschweig.

[24] Köhler, J., Klein, J. and Fontana, M. (2006) Die Erhebung von Brandlasten in 95 Industrie- und Gewerbebauten. Bauphysik, 28, 360-367.

https://doi.org/10.1002/bapi.200610038

[25] Huchanan, A., et al. (2001) Fire Engineering Design Guides. Center for Advanced Engineering, University of Canterbury, Christchurch, New Zealand.

[26] Schneider, U. (2009) Ingenieurmethoden im Brandschutz. Expert-Verlag GmbH, Köln.

\section{Nomenclature Listing}

\begin{tabular}{|c|c|c|}
\hline$A$ ground area $\left(\mathrm{m}^{2}\right)$ & $\mathcal{\vartheta}_{\max }$ & maximum temperature $\left({ }^{\circ} \mathrm{C}\right)$ \\
\hline$H_{c}$ heat of combustion $(\mathrm{kJ} / \mathrm{kg})$ & $\mathcal{\vartheta}_{\text {mid }, 0.7}$ & $\begin{array}{l}\text { average mean temperature in a height } \\
\text { of } 0.7 \text { above floor }\left({ }^{\circ} \mathrm{C}\right)\end{array}$ \\
\hline$M$ weight $(\mathrm{kg})$ & Greek & \\
\hline$Q$ fire load $\left(\mathrm{MJ} / \mathrm{m}^{2}\right)$ & $\chi$ & combustion efficiency \\
\hline$Q^{\prime \prime}$ fire load density $\left(\mathrm{MJ} / \mathrm{m}^{2}\right)$ & subscripts & \\
\hline $\mathcal{\vartheta}$ temperature $\left({ }^{\circ} \mathrm{C}\right)$ & $i$ & particular species \\
\hline
\end{tabular}

